sions, and especially on such as were contained in the Report of a Commission the constitution of which was such as to inspire the greatest respect, since men so eminent as Prof. Huxley and Mr. Holdsworth were named in it. That Commission reported in effect that there was nothing to be done with our sea-fisheries but to leave things alone. I do not profess to quote the words of the Report (which, indeed, I have not seen for a long time); but in substarce, I believe, it amounted to this:-That the natural enemies to which fishes were exposed were so multitudinous, so crafty, and so rapacious, that their destruction by man was very slight in comparison, and that his interference might be safely neglected in considering its consequences. Now it has always seemed to me that the Commissioners on this occasion suffercd themselves to be deceived. Well aware of how little is known as to the indirect effects of man's acts in regard to the lower animals, and in their fear lest any unforeseen bad results should follow from measures intended to be remedial, they recommended none at all. But I fail to discern that land or sea makes any essential difference in the laws of life. The balance of nature must be preserved as steadily in a dense as in a rare Huid -in water as in air--or all will not go well. Whatever be the weight in either scale, equipoise is as easily destroyed by an ounce as by a ton. The marine fishes that are of such commercial importance (cod, herrings, and the like) have naturally, no doubt, enemies innumerable-dogfish, cormorants, porpoises, and what not; but we know that, owing to their fertility and habits, the cod and herrings have continued till lately to contend successiully with these drawbacks and to maintain their numbers. It matters not if only one egg of the 10,000 , or whatever be the number in the roe of a herring, produces a fish that arrives at maturity and escapes its natural enemies, so long as that one fish is sufficient to supply the place of its parent. Now this, according to the arrangement of nature, has hitherto been the case. But if, instead of that fish living to propagate its kind, it is cut off before its time by an enemy against whom nature has made no provision, her balance is at once destroyed; and the oftener the operation is repeated the sooner will the numbers of the species dwindle; and the dwindling will go on in a rapidly accelerated ratio. Therefore it seems that, so far from leaving our sea-fisheries unrestricted, it is highly necessary to impose some limitation upon them; and, so far from dreading interference, our interference is at present so fatal that further interference of another kind is required as a counterbalance; while that counterbalance science only can apply.

As much may be said for those other industries, in common speech also called "fisheries"--the taking of oysters, crabs, and Iobsters, all of which have lately been diminishing in a still more alarming degree. Here Parliament has wisely resolved to interpose, though whether the manner of interposition is wise seems to be a matter on which, as few naiuralists have been consulted, we had better reserve our opinion.

Thus, without troubling you with many technical details, I have striven to lay before you a sketch of man's treatment of some of his fellow.creatures, and of the effects which have sprung, or certainly will spring, from it. There is probably hardly an island on which he has set foot the fauna and flora of which has not been in some degree influenced by his even temporary presence; there is assuredly not a continent, though a continent takes longer to subdue: and his control does not stop at the shore; for, if what I have been advancing is true, the inhabitants of the deep come also more or less under his dominion. I invite you to contemplate whether it is aiways, or even generally, that of a beneficent ruler. But it will, doubtless, be urged that this kind of thing has gone on for ages-ever since life first existed on the earth. I may be told, in the words of the gxeat poet of the conntry in which we now find ourselves-

$$
\begin{aligned}
& \text { "Look abroad through Nature's range, } \\
& \text { Nature's mighty law is change; } \\
& \text { * Why then ask of silly man, } \\
& \text { To oppose great Nature's plan?" }
\end{aligned}
$$

I would answer from the same source that

$$
\text { "A-man, to whom alone is giv'n, }
$$

should by means of that ray not oppose nature, but rather second her preservative measures. That ray is the ray of science. We can only govern nature by obeying her, only by obeying her can we assist her. To obey her laws we must know them; what can we know of them but what science teaches us?

It may be said that I have taken too gloomy a view of this matter of the extirpation of animals by man. I wish I could think so. But $\mathrm{I}$ believe that if we go to work in the right way there is yet time to save many an otherwise expiring species. In this country there is happily a strong disposition, which grows stronger day by day, to preserve our wild animals. It is very desirable that this feeling should not be limited to the British Islands. If it is, as I maintain, a right feeling - a feeling sanctioned alike by humanity, by science, and by our own material interests-it cannot be too widely disseminated. But its propagation must not be left to humanitarians and sentimentalists, whose efforts are sure to be brought to nothing through ignorance and excess of zeal, nor to economists, whose endeavours would unquestionably fall short of what is required. The officiousness of the one class and the slackness of the other must equally be tempered by the naturalist. He can be trusted not to interfere with the use, but with the abuse, of the animal world. Only to do this he must place himself in the forefront of the movement; for he can submit to no other leader. He alone has, or should have, that knowledge which gives the power of coping successfully with the difficult questions that will arise ; and the advantage it gives him he must not abstain from exercising. If, without offence, I might here paraphrase some venerable words, I would say that, according to the greatness of this power, we must preserve those that are otherwise appointed to die.

\section{THE NORWEGIAN ATLANTIC EXPEDITION'}

$I N$ continuation of my last notice, I may say that the Expedition stayed at Reikiavik from July 26 to Aug. 3. While Capt. Wille marle magnetical observations on shore, the majority of the members of the expedition made a tour to Thingvalla, where they had the pleasure of falling in with an Englishman coming from the north and bound for the Geysers; we had a very happy evening together. The remarkable geological structure of the country attracted much interest. The excursion party returned July 30. Stormy weather prevailed during the whole stay at Reikiavik, so that the coaling was much delayed, and no magnetical observations could be made on shore. A small leak in the boiler took up most of the last day to set it right, and at last we got away on the evening of the $3 \mathrm{rd}$. The season was now so far gone that we were obliged to give up the idea of exploring the sea between Iceland and Greenland, and we shaped our course south of Iceland again, and then towards N.E., running out a line of soundings which showed the transition from the warmer Atlantic water at the bottom, to the ice-cold Arctic water east of Iceland. During a dredging on the bank, between Iceland and Färöe, on a hard, probably volcanic, bottom, the line got fast on a ruck, and it became necessary to break it ; we thus lost a dredge and some hundred fathoms of dredging line. From a point east of Iceland, the course was laid for Namsos, and several deep sea stations were well explored on this line. The depth at first increased from I, 000 fathoms to I, 500 , and at last to 1,800 , the last being midway between Norway and Iceland in lat. $64^{\circ} 65^{\prime}$. The more easterly soundings gave a less depth, the last of them being only 650 fathoms. The temperature at the bottom was always under $32^{\circ}$; at $\mathbf{I}, 800$ fathoms it was $29^{\circ}$, corrected for the error of the thermometer, and for that caused by pressure. The layer with $32^{\circ}$ was found in about 200 fathoms east of Iceland, and in 300 or 400 fathoms further east. It seems that the Färöe bank preverts the warm Atlantic water from filling up the upper layers of the northern seas to such a depth on the north-east side of these islands, as it does in the interval between this region and the cold sea east of Iceland. The nearer Norway the warmer is thas upper layer of the sea, not only on the surface, but at the depths of 100 and 200 fathoms.

The fauna of the Arctic deep sea seems to be very constant, while it is not very rich; the same specimens have been found farther south in ice-cold water, but none of the large forms found in ice-cold water near the coasts (were met with by us ${ }^{2}$ ). The bottom consists of mud, with innumerable specks of small round calcareous shells.

During the last cruise, the weather was constantly bad; nevertheless, it has been possible to work the deep-sea apparatus even in gales, and with a sea in which the ship went bowsprit under. This result has been attained after successive experiments. The last working day the dredge and trawl were sent out together, the latter behind the former. The weather was stormy, the sea very high, but the experiment was made, and the dredge came well on board. After this result, we can now see no objection to working all the deep-sea apparatus in any kind of summer

I Contunued from $\mathrm{p} \cdot 33^{8}$.

2 Probable omission in origiral. 
weather when the depth does not exceed 600 or 700 fathoms. Unhappily, in bad weather, the zoologists cannot study the specimens found in a living state, the motion of the ship killing the animals very soon. The Expedition arrived at Namsos August 14, the scientific staff and the crew being much exhausted by the perpetual bad weather. At Namsos we stayed till the 2oth to rest. Meanwhile magnetical observations were made on shore. On board, the bad weather entirely prohibited our making any.

After leaving Namsos, series of soundings every four miles (nautical) were taken from the Folden-fjord, and due west. First we found a hollow 200 fathoms deep, with a constant temperature of $7^{\circ} \mathrm{C}$., then a slightly inclined ridge, whose highest point shoaled up to 56 fathoms, then came an incline down to 120 to 150 fathoms, and after that a flat bottom at the last-named depth. Over this flat the temperature was constantly $7^{\circ}$ C. At last, about II o'clock on Monday the 2Ist, the depth increased, the temperature decreased, and we found ice-cold water in somewhat more than 300 fathoms depth. This was IOO nautical miles off the nearest coast and not very far from our last deep-sea station, where the depth was 580 fathoms, temperature $-I^{\circ} \cdot 3$. Such an extent of the Norwegian banks at this place was not expected, but is very interesting. It now seems probable that the boundary line of the ice-cold water runs from a point Ioo miles off the coast at Namsos up to Spitzbergen, outside the Lofoden Islands, and this breadth of the bank explains the mild winter climate which Northern Norway enjoys. As a series of soundings and temperatures showed the next day in a line direct from west to east in the latitude of the mouth of the Trondhjem-fjord, the boundary of the bank and of the icecold water goes here and off Romsdal much nearer to the coast. The water was at $0^{\circ} \mathrm{C}$. in 345 fathoms, and at the bottom $-\mathrm{I}^{\circ} \times \mathrm{C}$. in 480 fathoms depth. On the bank inside there was a temperature of $7^{\circ} 3$ on the bottom at 170 fathoms depth. On the morning of the 23 rd the Vöringen was outside the coast of Romsdal, and in foggy weather got very near the dangerous coast. Happily the fog lifted and a pilot came on board, who took the ship into Molde. The next day the expedition was sounding, trawling - with no result-and taking serial tempera. tures in the Romsdal-f jord. The result was the same temperature in the depth of the fjord as in the other deep fjords on the west coast of Norway, viz, $6^{\circ} \cdot 2$. In the evening the expedition arrived at Aalesund, where the ship in a very strong gale was nearly driven ashore in the harbour. Happily the wind abated and the chains $h \in l i$, so that the voyage could be continued the next morning.

On Saturday, August 26, the expedition returned to Bergen, where the ship will be paid off. The members of the expedition are all very well and look with much interest to the time when they can commence to discuss their observations which, in spite of the bad weather generally experienced this summer during the cruise, are numerous and interesting.

\section{NOTES}

The Prussian Government has sent the following gentlemen to examine thoroughly the special Loan Collection of Scientific $\Lambda$ pparatus, and to report on the objects exhibited:-From the Ministry of Commerce--Professors-Doctors Landolt, Aix.la. Chapeile; Krant, Hanover; Liebermanr, Berlin; Wüllner, Air-la Chapelle; von Quintus-Icilius, Hanover; Gerland, Cassel ; Tanlzow, Berlin; Helmert, Aix-la-Chapelle; Stahl, Aix-la-Cbapelle; Dörgens, Berlin. From the Ministry of Education-Professors-Doctors Cronecker, Leipzig; Abbe, Jena; Hensen, Kiel ; Karsten, Kiel; Herr Appuun, Hanau; Pro. essors Doctors Kundt, Strasburg; Listing, Göttingen ; Cohn, Breslau ; Lassaulx, Breslau. Bruns, Berlin; Löwenhorz, Berlin. From the Ministry of Agriculture-Dr. Scheibler, Berlin.

ThE annual meeting of the Ray Society was held in Glasgow on Friday under the presidency of Prof. Young. The secretary, Rev. T. Wiltshire, submitted the report of the council, in which they congratulate the members upon the progres; of the Society. With regard to the issue of the volumes, some unexpected delays, chiefly due to the lengthened period requisite for the careful colouring of the plates, have hindered the appearance of the work for the year 1875 . As, however, all the plates are at the present moment coloured, and most of the text in type, it is certain that the book will be published within a brief period. Originally it was proposed that the volume for 1875 should comprise a description by Mr. G. B. Buckton of the whole of the British Aphides. The plan suggested at the commencement has, from the exigencies of the case, been somewhat defeated; the re searches of Mr. Buckton have brought to light so many new species that it seems probable that the Monograph will require at least two, if not three, volumes of text and plates. The first of these, containing forty coloured plates and the necessary introduction, will form the publication for the year 1875 . The succeeding parts are now being proceeded with, and will be ready as soon as an opportunity offers for their issue. Since last annual meeting Prof. Huxley had offered to prepare an introduction to the MS. of the Tunicata left by the late Mr. Hancock, and Mr. Cameron had proposed a monograph on the British Tenthredinidæ. These have been accepted, and will be com. menced with all possible speed. On account of the changing location of the British Association, the Council propose that for the future the annual meetings be held in London within three months of Lady-day. It was recommended that the fol lowing names be added to the Council :-Prof. Bentley, Sir A. Brady, Dr. Gwyn Jeffreys, and Mr. Hudson. The statement of accounts showed that there was a balance in favour of the Society of $£ 15^{6}$ I8s. $11 a$. On the motion of Prof. Balfour, the report was adopted. Votes of thanks were subsequently passed to the retiring members of Council and to Prof. Young for presiding, and the meeting separated.

A General meeting of the Mineralogical Society of Great Britain and Ireland was held in the Natural History Class Room of the Glasgow University on Wednesday, Sept. 6 . The chair was taken by Prof. M. Forster Heddle, M.D., in the absence of the president, Mr. H. C. Sorby, and there was a large attend. ance. The chairman delivered an address on "Scotch Minerals, how and where to find them." This was followed by the read. ing of a paper by the president "On the Critical Point in the Consolidation of Granite." Prof. Haughton, of Trinity College, Dublin, then followed with an address on a new principle in the consolidation of porphyritic rocks, which he proposed to call "the principle of least paste." Some discussion of this principle and of Mr. Sorby's paper then took place, in which Prof. Harkness and Dr. Bryce joined. The following papers were afterwards read:--_"On a Mineral from New South Wales, presumed to be Laumontite," by Prof. A. Liversidge; "Notes on an Old Catalogue of Minerals," by Prof. A. H. Church; "On the Occurrence of Achroite at Rock Hill, in the Parish of St. Austell, Cornwall, and on the Black Tourmaline of the same I.ocality," by J. H. Collins.

THE Oriental Congress, which met at St. Petersburg during the first ten days of the present month has been doing much good work in its own department. Many papers have been read, most of them connected with Russian, or at least Asiatic Russian, ethnolozy and archæology. The members of the Congress have been heartily welcomed and well treated at the Russian capital, and among those who have enrolled themselves members is the ubiquitous Emperor of Brazil. Among the papers read was an important one on the "Caucasian Race," by Prof. Gregorief, in which he pointed out the acciclental origin and the unsuitability of the term, and endeavoured to trace the origin and migrations of the race indicated. He showed that even at the present day many Aryans are to be found in Central Asia. Mr. Berger made a communication on many of the ethnographical objects belonging to the Caulcasian Department of the Congress's Exhibition. Another paper on the Aryan Race was by the Rev. Mr. Long, of Calcutta, and Prof, Oppert remarked on the Asiatic tongues 